\title{
Vitamin D supplementation in paediatric acute respiratory tract infection- is it really advocated?
}

\author{
Haribhakta S.V ${ }^{1}$, Pratinidhi S.A ${ }^{2}$, Ambike D.A ${ }^{3}$, Chindarkar $\mathrm{A}^{4}$ \\ ${ }^{1}$ Dr. S.V. Haribhakta, Assistant Professor, Department of Pediatrics, ${ }^{2}$ Dr. S.A. Pratinidhi Professor and Head, Department \\ of Biochemistry, ${ }^{3}$ Dr. D.A. Ambike, Professor and Head, Department of Paediatrics, ${ }^{4} \mathrm{Mr}$ Abhishek Chindarkar, Third \\ year MBBS student, all authors are affiliated with MIMER Medical College and Dr BSTR Hospital, Talegaon (D).
}

Address for Correspondence: Dr Sandhya Haribhakta, Assistant Professor (Pediatrics) M.I.M.E.R Medical College, Talegaon (D) District: Pune. Email id: sandhyaharibhakta@live.com

\begin{abstract}
Objectives: 1.To estimate the level of serum 25 hydroxyvitamin D [25(OH)D] levels in patients of Acute respiratory tract infections (ARTI) admitted in the pediatric ward of a rural hospital. 2. To study the association between vitamin D deficiency and respiratory tract infections by estimating serum 25 hydroxyvitamin D [25(OH)D] levels in these patients. Materials and Methods: A hospital-based observational study was carried out in the patients admitted for ARTI from pediatric ward over 6 month's duration. A total of 52 subjects between the age group 2 to 60 months were selected for the study. Results: Average Vitamin D levels were $39.6 \mathrm{ng} / \mathrm{dl}$. On the basis of results of Vitamin D level it has been divided into four categories namely, deficient, insufficient, sufficient, and toxic. The number of children with deficient levels and insufficient levels were $33(63 \%)$, sufficient levels were $11(21 \%)$, where as those with toxic levels were 8 (15\%). Conclusion: Vitamin D levels are found to be lower in 63\% cases of ARTI. However $15 \%$ children had Vitamin $\mathrm{D}$ levels in a toxic range. Therefore Vitamin D should not be arbitrarily administered in a therapeutic dose in all children with ARTI. Vitamin D supplementation is to be given after estimation of Vitamin D levels in all ARTI patients. There is a need of more studies to be done on a larger sample size to reach to a certain conclusion.
\end{abstract}

Keywords: Respiratory tract infections, Vitamin D supplementation, ARTI

\section{Introduction}

Respiratory tract infections (RTIs) are common worldwide and are responsible for significant morbidity and mortality. According to a recent report, 2.8 million deaths were caused by RTI during 2010 [1]. Acute lower respiratory infection (ALRI) is one of the most common reasons for hospitalization and intensive care unit admission among children [3]. Acute respiratory tract Infections are major cause of morbidity and mortality in children below five years of age. Vitamin $\mathrm{D}$, a sun shine vitamin is one of the many nutrients our body needs to stay healthy. Among the vitamin's main functions, it helps the body to absorb calcium, along with phosphorus from intestine. It helps to build bones and keep them strong and healthy. In immune cells, VDR activation elicits potent anti-proliferative, prodifferentiate, and immunomodulatory effects. Regulation of intestinal calcium transport is still the

Manuscript received: $8^{\text {th }}$ October 2016

Reviewed: $20^{\text {th }}$ October 2016

Author Corrected; $10^{\text {th }}$ November 2016

Accepted for Publication: $30^{\text {th }}$ November 2016 most significant effect of $1,25 \mathrm{D}$ acting through its binding to the VDR. It has become clear that vitamin D has pleiotropic effects, including some VDR transcription-independent actions and plays a key role in immune system regulation. Activation of the VDR by $1,25 \mathrm{D}$, the active form of vitamin $\mathrm{D}$ alters cytokine secretion patterns, suppresses effector $\mathrm{T}$ cell activation and induces regulatory $\mathrm{T}$ cells. In dendritic cells, it has also been demonstrated to affect maturation, differentiation and migration. 1,25D can enhance the phagocytic activity of macrophages and increase the activity of natural killer cells. Therefore, tissue and cell specific differences in the regulation of 25D are highly relevant to the roles of $25 \mathrm{D}$ and1,25D as immunemodulators.

The human body thus procures vitamin D through two independent pathways: the photochemical action of solar UVB light ( $\approx 295$ to $320 \mathrm{~nm}$ ) in the skin and some limited dietary sources [4]. For adults, consumption of 
fatty fish and/or oral supplementation supplies the most abundant amounts of vitamin D3. In contrast, the major dietary sources of vitamin $\mathrm{D}$ in the pediatric population are provided by fortified foods such as cereal, cheese, and milk, Vitamin D may also play a role in muscle function and the immune system.

The immune system is your body's defense system Thereby helping children to fighting infections. In children, an association between nutritional rickets with respiratory infection has long been recognized [1].

Recent epidemiological studies clearly demonstrate the link between vitamin D deficiency and the increased incidence of respiratory infections [2]. There is a possible role for vitamin D supplementation in children with respiratory tract infection. In winter season a decrease in the immunomodulatory molecule i.e. vitamin $\mathrm{D}$, remains an unexplored factor that might contribute to the increased occurrence of ALRI season.

Several studies have associated vitamin D deficiency with an increased risk of ARTIs, and vitamin D supplementation has been proposed as a possible preventive measure against ARTIs in children [3].

This study was undertaken to estimate a possible association between vitamin D deficiency and respiratory infection by estimating serum 25 hydroxyvitamin $\mathrm{D}[25(\mathrm{OH}) \mathrm{D}]$ levels in a group of young children with ALRI children.
To estimate a possible association between vitamin D deficiency and respiratory tract infection by estimating serum 25 hydroxyvitamin D [25(OH)D] levels in a group of young children with ARTI .

\section{Materials \& Methods}

A hospital-based observational study was carried out in the children selected from pediatrics ward of a Rural Hospital over 6 months duration. A total of 52 nonconsecutive cases of ARTI between the age group 2 to 60 months were selected for the study.

The study was approved by the institutional ethical committee. Case definition of ALRI as given by the World Health Organization was used for cases. Along with the general examination, anthropometry was done and it included weight, height and BMI.

Two $\mathrm{ml}$ venous blood was collected by venipuncture in plain dried containers for estimation of serum 25 hydroxyvitamin D [25(OH)D] levels. 25(OH) D levels were measured in serum using a competitive enzyme linked immunoassay.

\section{Inclusion Criteria: All cases of ARTI}

Exclusion Criteria: 1. Hyperactive airway disease, 2. Pulmonary tuberculosis, 3. Sepsis, 4. Other immunedeficient diseases. Statistical analysis was done using SSPS software in consultation with the statistician.

\section{Aim \& Objectives}

\section{Results}

The study was carried out in 52 children admitted in the pediatric ward with ARTI in our rural hospital of Medical College in Maval Taluka.

The male to female ratio was 4.2:1; Average age in years was 4.5. Average Vitamin D levels were $39.6 \mathrm{ng} / \mathrm{dl}$ On the basis of the levels of vitamin D levels; children were divided the group into four categories namely, deficient, insufficient, sufficient and toxic. The percentage wise deficient and insufficient cases were $63 \%(n=33)$ where as those of toxicity were $15 \%(\mathrm{n}=8)$ sufficiency were $21 \%(\mathrm{n}=11)$ as in table no 1 .

Table No-1: Vitamin D levels in various categories.

\begin{tabular}{|c|c|c|c|}
\hline Category & Level of VIT D & No of Cases & Percentage \\
\hline Sufficient (30-100 ng/dl) & $34.73 \mathrm{ng} / \mathrm{dl}$ & 11 & 21 \\
\hline Deficient ( less than $20 \mathrm{ng} / \mathrm{dl}$ ) & $11.46 \mathrm{ng} / \mathrm{dl}$ & 14 & 26 \\
\hline Insufficiency (20-30 ng/dl) & $20.04 \mathrm{ng} / \mathrm{dl}$ & 19 & 36 \\
\hline Toxicity (more than $100 \mathrm{ng} / \mathrm{dl}$ ) & $289.36 \mathrm{ng} / \mathrm{dl}$ & 8 & 15 \\
\hline
\end{tabular}




\section{Discussion}

In our study we found that low levels of vitamin $\mathrm{D}$ were found in $63 \%$ of cases. Various reasons are given for the protective action of vitamin $\mathrm{D}$ in prevention of respiratory tract infections. It is thought that vitamin $\mathrm{D}$ increases the production of natural antibodies [4,5]. Vitamin $\mathrm{D}$ is also known to strengthen the immunity by inducing monocyte differentiation and inhibiting lymphocyte proliferation [8]. It also postulated that vitamin $\mathrm{D}$ enhances the phagocytic activity of macrophages [7].

There is a considerable discussion on the serum concentrations of $25(\mathrm{OH}) \mathrm{D}$ associated with deficiency (e.g., rickets), adequacy for bone health, and optimal overall health, and cut off points have not been developed by a scientific consensus process. Based on its review of data of vitamin D, a committee of the Institute of Medicine concluded that persons are at risk of vitamin D deficiency at serum 25(OH)D concentrations $<30 \mathrm{nmol} / \mathrm{L}(<12 \mathrm{ng} / \mathrm{mL})$. Some are potentially at risk for inadequacy at levels ranging from $30-50 \mathrm{nmol} / \mathrm{L}(12-20 \mathrm{ng} / \mathrm{mL})$. Practically all people are sufficient at levels $\geq 50 \mathrm{nmol} / \mathrm{L}$ ( $\geq 20 \mathrm{ng} / \mathrm{mL}$ ); the committee stated that $50 \mathrm{nmol} / \mathrm{L}$ is the serum $25(\mathrm{OH}) \mathrm{D}$ level that covers the needs of $97.5 \%$ of the population. Serum concentrations $>125 \mathrm{nmol} / \mathrm{L}(>50 \mathrm{ng} / \mathrm{mL})$ are associated with potential adverse effects [ 9] (Table 2).

\begin{tabular}{|c|c|c|}
\hline \multicolumn{3}{|r|}{ Table-2: Serum 25-Hydroxyvitamin D [25(OH)D] Concentrations and Health* [ 9 ] } \\
\hline $\mathbf{n m o l} / \mathbf{L} * *$ & $\mathbf{n g} / \mathbf{m L} *$ & Health status \\
\hline$<30$ & $<12$ & $\begin{array}{l}\text { Associated with vitamin D deficiency, leading to rickets in infants and children and } \\
\text { osteomalacia in adults }\end{array}$ \\
\hline $30-50$ & $12-20$ & Generally considered inadequate for bone and overall health in healthy individuals \\
\hline$\geq 50$ & $\geq 20$ & Generally considered adequate for bone and overall health in healthy individuals \\
\hline$>125$ & $>50$ & $\begin{array}{l}\text { Emerging evidence links potential adverse effects to such high levels, particularly }>150 \\
\mathrm{nmol} / \mathrm{L}(>60 \mathrm{ng} / \mathrm{mL})\end{array}$ \\
\hline
\end{tabular}

* Serum concentrations of $25(\mathrm{OH}) \mathrm{D}$ are reported in both nanomoles per liter $(\mathrm{nmol} / \mathrm{L})$ and nanograms per milliliter $(\mathrm{ng} / \mathrm{mL})$.

** $1 \mathrm{nmol} / \mathrm{L}=0.4 \mathrm{ng} / \mathrm{mL}$

Similarly studies conducted by Mc Nally et al [8] found that significantly more children admitted to the pediatric intensive care unit with ALRI were vitamin D deficient. In a study by Esposito et al [9] Here they found that associated vitamin D deficiency is with an increased risk of RTIs, and vitamin D supplementation has been proposed as a possible preventive measure against RTIs in children. In this regard, it is very important to understand the definition and insufficiency of vitamin $\mathrm{D}$ and when and how to treat this condition.

Unfortunately, there is no consensus, although a level of at least $10 \mathrm{ng} / \mathrm{mL} 25$-hydroxycholecalciferol (25[OH] D) is thought to be necessary to promote bone mineralization and calcium homeostasis, and a concentration between $20 \mathrm{ng} / \mathrm{mL}$ and $50 \mathrm{ng} / \mathrm{mL}$ is considered adequate to provide an immunomodulatory effect. Available data support a role for vitamin $\mathrm{D}$ deficiency in reducing the risk of pediatric tuberculosis, recurrent acute otitis media, and severe bronchiolitis, whereas further studies are needed to confirm an association in children with recurrent pharyngo-tonsillitis, acute rhinosinusitis and community-acquired pneumonia.

In our study we also found that $15 \%(\mathrm{n}=8)$ had the levels in the toxic range, this figure is quite alarming as Frequent and unnecessary supplementation of vitamin $\mathrm{D}$ in treatment of respiratory infections is practiced by many doctors before they are referred to our hospital. Antibiotics are the mainstay of treatment for pneumonia. In the developing countries, zinc and vitamin A supplementation has been studied for the prevention and treatment of ARI. There is bombardment of the fact that Vitamin D is considered to be important for a healthy immune system. Vitamin D supplementation reduces frequency of respiratory tract infections (RTIs) and prolongs the time of the second ARTI in adult patients with frequent RTIs. This practice of supplementation is sometimes followed in pediatrics, but it is absolutely essential that the levels of vitamin D should be checked and then only the supplements should be given. 


\section{Conclusion}

On the basis of this study, we conclude that vitamin D deficiency is associated with respiratory tract infections. However few patients had toxic levels of Vitamin D, therefore supplementation of Vitamin D in each and every case of ARTI may not be advocated and a need of measuring the levels of vitamin D prior to any supplementation is advisable.

Limitation: This is only a preliminary study and larger studies need to be done so that valid conclusion can be reached.

Acknowledgement: We acknowledge and are indebted to the research Society of our college for the funding and research facilities provided. We express our deep gratitude to all who consented to volunteer in this project.

Contributors: Study concepts and design- SP and DA, Data collection- SH. Follow up of Subjects- AC. Statistical Analysis- SP. All authors had equal contributions in writing this manuscript and all have read and approved the final manuscript.

\section{Competing Interests: NIL}

The authors declare that they have no competing interests.

\section{Funding: Nil, Conflict of interest: Nil \\ Permission from IRB: Yes}

\section{References}

1. Bergman P, Norlin AC, Hansen S , BjörkhemBergman. Vitamin D supplementation to patients with frequent respiratory tract infections: a post hoc analysis of a randomized and placebo-controlled trial LBMC Res Notes. 2015 Aug 30;8:391. DOI: 10.1186/s13104015-1378-3.

2. McNally JD, Leis K, Matheson LA, Karuananyake C, Sankaran K, Rosenberg AM. Vitamin D deficiency in young children with severe acute lower respiratory infection. Pediatr Pulmonol. 2009 Oct;44(10):981-8. doi: $10.1002 /$ ppul.21089.

\section{How to cite this article?}

Haribhakta S.V, Pratinidhi S.A, Ambike D.A, Chindarkar A. Vitamin D supplementation in paediatric acute respiratory tract infection- is it really advocated?. Int. J Pediatr Res. 2016;3(11):814-817.doi:10.17511/ijpr.2016.i11.08.
3. Diaz L, Sanchez I, Avila E, Halhali A, Vilchis F, Larrea F. Identification of a 25-hydroxyvitamin D3 1alpha-hydroxylase gene transcription product in cultures of human syncytiotrophoblast cells. Diaz L, Sanchez I, Avila E, Halhali A, Vilchis F, Larrea F. J Clin Endocrinol Metab 2000;85:2543-2549.

4. Mawer EB, Hayes ME, Still PE, Davies M, Lumb GA, Palit J, Holt PJ. Evidence for nonrenal synthesis of 1,25-dihydroxyvitamin $\mathrm{D}$ in patients with inflammatory arthritis. J Bone Miner Res. 1991 Jul;6(7):733-9.

5. Lin R, White JH. The pleiotropic actions of vitamin D. Bioessays. 2004 Jan;26(1):21-8.

6. Rallof $\mathrm{J}$. The antibiotic vitamin.Deficiency in vitamin D may predispose people to infection. Science. 2006; $170: 312$

7. Liu PT, Stenger S, Li H, Wenzel L, Tan BH, Krutzik SR, Ochoa MT, Schauber J, Wu K, Meinken C, Kamen DL, Wagner M, Bals R, Steinmeyer A, Zügel U, Gallo RL, Eisenberg D, Hewison M, Hollis BW, Adams JS, Bloom BR, Modlin RL. Toll-like receptor triggering of a vitamin D-mediated human antimicrobial response. Science. 2006 Mar 24;311(5768):1770-3. Epub 2006 Feb 23.

8. McNally JD, Leis K, Matheson LA, Karuananyake C, Sankaran K, Rosenberg AM. Institute of Medicine, Food and Nutrition Board. Dietary Reference Intakes for Calcium and Vitamin D. Washington, DC: National Academy Press, 2010. 10Vitamin D deficiency in young children with severe acute lower respiratory infection. Pediatr Pulmonol. 2009 Oct;44(10):981-8. [DOI: 10.1002/ppul.21089.]

9.Esposito S, Lelii M. Vitamin D and respiratory tract infections in childhood. BMC Infect Dis. 2015 Oct 28;15:487. doi: 10.1186/s12879-015-1196-1.

10. Ahmed P, Babaniyi IB, Yusuf KK, Dodd C, Langdon G, Steinhoff M, Dawodu A. Vitamin D status and hospitalisation for childhood acute lower respiratory tract infections in Nigeria. Paediatr Int Child Health. 2015 May; 35(2):151-6. doi: 10.1179/ 2046905514Y. 0000000148. Epub 2014 Oct 21. 